\title{
DAYA DUKUNG LINGKUNGAN BERBASIS KEMAMPUAN LAHAN DI TUBAN, JAWA TIMUR \\ (Land Capability Based Environmental Carrying Capacity in Tuban, East Java)
}

\author{
Widiatmaka $^{1 *}$, Wiwin Ambarwulan ${ }^{2}$, Muhamad Yanuar Jarwadi Purwanto ${ }^{3}$, Yudi Setiawan ${ }^{4}$ \\ dan Hefni Effendi ${ }^{4}$ \\ ${ }^{1}$ Departemen Ilmu Tanah dan Sumberdaya Lahan, Fakultas Pertanian, Institut Pertanian Bogor, \\ Kampus Darmaga, Bogor 16680. \\ ${ }^{2}$ Badan Informasi Geospasial, Jalan Raya Bogor-Jakarta Kilometer 46, Cibinong, Bogor 16911. \\ ${ }^{3}$ Departemen Teknik Sipil dan Lingkungan, Fakultas Teknologi Pertanian, Institut Pertanian Bogor, \\ Kampus Darmaga, Bogor 16680. \\ ${ }^{4}$ Pusat Penelitian Lingkungan Hidup, Institut Pertanian Bogor, Kampus Darmaga, Bogor 16680. \\ *Penulis korespondensi. No Tel: 081314065828; Email: widiatmaka@ipb.ac.id.
}

Diterima: 12 Januari 2015

Disetujui: 29 April 2015

\begin{abstract}
Abstrak
Evaluasi daya dukung lingkungan merupakan bagian dari upaya mewujudkan pembangunan berkelanjutan. Salah satu metoda evaluasi daya dukung lingkungan adalah evaluasi berbasis kemampuan lahan. Penelitian ini bertujuan untuk melakukan evaluasi daya dukung lingkungan berbasis kemampuan lahan di Tuban, Jawa Timur. Evaluasi dilakukan dengan mengkaji kesesuaian antara kemampuan lahan dengan penggunaan lahan aktual dan alokasi Pola Ruang dalam Rencana Tata Ruang Wilayah Kabupaten. Kemampuan lahan dievaluasi pada setiap Satuan Peta Lahan yang diperoleh dari survai lapangan tahun 2014. Penggunaan lahan aktual dianalisis menggunakan citra Landsat 8 OLI tahun peliputan 2013. Hasil analisis menunjukkan bahwa kemampuan lahan di wilayah penelitian berkisar dari kemampuan lahan kelas II sampai kelas VIII. Wilayah dengan kemampuan lahan yang memungkinkan untuk pengusahaan budidaya (kelas II-IV) mencakup 78,6\% wilayah studi, sementara wilayah yang tidak memungkinkan untuk budidaya (kelas V-VIII) mencakup 21,4\% wilayah studi. Faktor pembatas kemampuan lahan terdiri dari tekstur tanah, kedalaman efektif, drainase, lereng dan genangan/banjir. Saat ini, 32\% wilayah di Kabupaten Tuban penggunaan lahannya sesuai dengan kemampuan lahannya, $66,4 \%$ wilayah digunakan melebihi kemampuan lahannya. Dalam hal alokasi lahan pada pola ruang, $67,3 \%$ wilayah dialokasikan penggunaan lahannya sesuai dengan kemampuan lahannya, sedangkan 31\% dialokasikan melebihi kemampuan lahannya. Temuan ini dapat digunakan untuk mengontrol penggunaan lahan di Kabupaten Tuban dan menjadi bahan revisi Rencana Tata Ruang Wilayah Kabupaten agar penggunaan lahan dialokasikan sesuai dengan kemampuan lahannya.
\end{abstract}

Kata kunci: evaluasi kemampuan lahan, interpretasi citra, perencanaan, survai tanah, tataguna lahan.

\begin{abstract}
Evaluation of the environmental carrying capacity should be done as part of sustainable land use planning. One of the method to evaluate carrying capacity is land capability based evaluation. This study aims to evaluate the land capability based carrying capacity of Tuban Regency, East Java Province. Evaluation is done by assessing the conformity between the land capability with current land utilization and land allocation of the Official Spatial Planning of the Regency. Land capability was evaluated for each land unit, which was obtained from soil survey, done in 2014. The current land use is analyzed using LANDSAT 8 OLI imagery of 2013. The results showed that the land capability in research areas was ranged from class III to class VIII. Area with land capability which support the agricultural uses (class I-IV) is $78.6 \%$ of total area, while the area which should not be used for agricultural cultivation (class V-VIII) was $21,4 \%$ of the total area. Factors limiting the land cability include soil texture, effective depth, drainage, slope, and flood. The area covering $32 \%$ of Tuban Regency is used in accordance with land capability, $66.4 \%$ is used exceeding land capability. There are $31 \%$ of the area that has been allocated in Official Spatial Planning of the Regency exceeds the land capabilities, while $67.3 \%$ has been allocated in accordance with land capability. The research result can be used as input to control land utilization in Tuban Regency as well as input for Official Land Use Planning revision.
\end{abstract}

Keywords: land capability evaluation, landuse planning, image interpretation, soil survey.

\section{PENDAHULUAN}

Lahan merupakan salah satu komponen abiotik lingkungan utama yang merupakan matriks dasar kehidupan (Tan, 2009). Evaluasi daya dukung lahan merupakan bagian dari evaluasi daya dukung lingkungan (Costantini, 2009). Salah satu cara untuk melakukan evaluasi daya dukung lingkungan 
adalah evaluasi berbasis kemampuan lahan. Melalui evaluasi tersebut, perencanaan penggunaan lahan dapat diarahkan agar lahan dapat digunakan sesuai dengan kemampuannya (Sharififar dkk., 2013), sehingga pemanfaatan dapat diarahkan sesuai daya dukungnya.

Lahan memiliki daya dukung terbatas, karena itu penggunaannya perlu dijaga agar tidak terjadi kerusakan atau degradasi (Stocking dan Murnaghan, 2002). Tekanan pertumbuhan penduduk yang tinggi di berbagai tempat telah menyebabkan tekanan terhadap lahan melalui penggunaan secara berlebihan. Degradasi terjadi pada lahan yang digunakan secara berlebihan melebihi kemampuan dan daya dukung alamiahnya (Goldshleger dkk., 2010). Degradasi lahan didefinisikan sebagai hilangnya kemampuan lahan untuk berproduksi, baik yang disebabkan oleh proses fisik maupun kimia (Singer dan Munns, 2002). Banyak penelitian menunjukkan terjadinya kemunduran kualitas lahan akibat penggunaan yang salah dan melebihi kemampuannya (Dougill dkk, 2002; Boix dan Zinck, 2008; Adamu dkk, 2014). Penggunaan lahan yang salah akan memerlukan biaya yang tinggi untuk memperbaiki, bahkan jika degradasi mencapai tahap irreversible, kerusakan tidak dapat diperbaiki lagi (Gupta dan Sharma, 2010; Sudershan, 2003).

Seperti juga pemanfaatan sumberdaya alam tak terbarukan lainnya, penggunaan lahan secara rasional merupakan salah satu indikator penting pembangunan (Chang dan $\mathrm{Wu}$, 2011) dan pertumbuhan ekonomi (Pilvere dkk, 2014). Hal ini bahkan terkait dengan konsep pembangunan berkelanjutan (Akinci dkk, 2013). Pembangunan berkelanjutan didefinisikan sebagai pembangunan yang memenuhi kebutuhan generasi saat ini tanpa mengorbankan kemampuan generasi mendatang untuk memenuhi kebutuhan mereka sendiri (Anonim, 1987; Munasinghe, 1993; Feizizadeh dan Blaschke, 2012). Pertumbuhan penduduk yang cepat membutuhkan daerah baru untuk pemenuhan kebutuhan primer, khususnya di kota besar. Pada gilirannya, kebutuhan ini menyebabkan sumberdaya alam seperti hutan, padang rumput, lahan basah dan lahan pertanian diubah menjadi pemukiman atau daerah industri dan menyebabkan lahan digunakan dengan cara-cara yang tidak sesuai dengan potensi dan melebihi daya dukungnya (Symeonakis dkk, 2007). Untuk menghindari hal ini, sangat penting mempersiapkan perencanaan penggunaan lahan yang memungkinkan pewarisan sumberdaya lahan untuk generasi mendatang dengan baik. Pendekatan terintegrasi perencanaan penggunaan lahan berkelanjutan juga secara eksplisit dinyatakan dalam Agenda 21 (Smardon, 2008). Hal ini dapat dilakukan melalui penggunaan lahan secara terencana dan berkelanjutan dan dengan cara yang sesuai dengan kemampuan dan potensinya.

Salah satu pendekatan dalam perencanaan penggunaan lahan adalah penilaian kemampuan lahan (Singer, 2014). Hasil penilaian selanjutnya dapat digunakan sebagai panduan menuju optimalisasi penggunaan lahan. Melalui penilaian tersebut, dapat diberikan informasi tentang kendala yang dimiliki lahan tertentu (Mokarram dan Aminzadeh, 2010), yang kemudian dapat digunakan sebagai alat pengambilan keputusan untuk penggunaan lahan berdasarkan kemampuan dan potensinya (Bandyopadhyay dkk, 2009). Pada tahap selanjutnya, melalui analisis kesesuaian lahan, dapat ditentukan jenis penggunaan lahan yang paling cocok (Amiri dan Shariff, 2012). Evaluasi dapat dilakukan dengan menilai kemampuan lahannya terlebih dahulu dan mengklasifikasikannya berdasarkan kriteria klasifikasi tertentu.

Klasifikasi kemampuan lahan yang biasa digunakan di berbagai negara pada dasarnya mengacu pada klasifikasi kemampuan lahan dari Departemen Pertanian Amerika Serikat (United States Department of Agriculture - USDA) (Klingebiel dan Montgomery, 1961; Helms, 1992; Fenton, 2014). Klasifikasi kemampuan lahan ini cukup praktis untuk digunakan karena relatif sederhana, hanya memerlukan data sifat-sifat fisik dan morfologi tanah dan sifat-sifat lahan yang dapat diamati di lapang, tanpa memerlukan data sifat kimia tanah yang harus dianalisis di laboratorium (Fenton, 2014), berbeda dari sistem evaluasi lahan dari FAO (Anonim, 1976). Sistem ini telah digunakan dalam pemetaan tanah detil di Amerika Serikat sejak tahun 1960-an hingga sekarang (Ditzler dan Ahrens, 2006) dan ternyata sangat membantu dalam perencanaan tataguna lahan.

Klingebiel dan Montgomery (1961) menyebutkan bahwa analisis kemampuan lahan merupakan analisis kualitatif. Sifat kualitatif ini menyebabkan evaluasi hanya memungkinkan dilakukan oleh ahli yang berpengalaman (Helms, 1992; Costantini, 2009). Dalam penerapannya di Indonesia, metoda ini dikuantitatifkan oleh Arsyad (2010). Hal ini telah mempermudah pelaksanaan evaluasi lahan di Indonesia dan membuat evaluasi menjadi lebih obyektif.

Beberapa penelitian telah dilakukan untuk memetakan kemampuan lahan, kebanyakan dilakukan dengan bantuan Sistem Informasi Geografi (Campos dkk, 2010; Adnyana dan Asysakur, 2012; Bulliqi dkk, 2012; Badaruddin dkk, 2013; Maleknia dkk, 2013). Kebanyakan penelitian menekankan pentingnya pengaturan penggunaan lahan untuk menjaga lahan dari tekanan 
perkembangan penduduk dalam konteks sumberdaya lahan yang terbatas.

Salah satu acuan yang harus digunakan di Indonesia dalam perencanaan tataguna lahan dan tata ruang adalah pengaturan melalui Rencana Tata Ruang Wilayah (RTRW), sebagaimana tertuang dalam Undang-undang Nomor 26 tahun 2007 tentang Penataan Ruang. Dalam RTRW, penggunaan lahan diarahkan melalui pengaturan dalam struktur ruang dan pola ruang. Evaluasi terhadap pola ruang dalam RTRW merupakan bagian dari langkah dalam pengelolaan tata ruang agar dapat disusun langkah yang diperlukan untuk perbaikan.

Dalam Undang-undang Nomor 32 Tahun 2009 tentang Perlindungan dan Pengelolaan Lingkungan Hidup, daya dukung lingkungan hidup didefinisikan sebagai kemampuan lingkungan hidup untuk mendukung perikehidupan manusia, makhluk hidup lain, dan keseimbangan antar keduanya. Evaluasi daya dukung lingkungan hidup kemudian diatur dalam Peraturan Menteri Lingkungan Hidup Nomor 17 Tahun 2009 tentang Pedoman Penentuan Daya Dukung Lingkungan Hidup dalam Penataan Ruang Wilayah. Ruang lingkup penentuan daya dukung lingkungan hidup dalam penataan ruang yang diatur meliputi kemampuan lahan untuk alokasi pemanfaatan ruang, pembandingan antara ketersediaan dan kebutuhan lahan, dan pembandingan antara ketersediaan dan kebutuhan air.

Dengan latar belakang tersebut, tujuan penelitian ini adalah untuk melakukan evaluasi daya dukung lingkungan hidup berbasis kesesuaian antara kemampuan lahan dengan penggunaan lahan aktual dan dengan alokasi lahan dalam pola ruang pada Rencana Tata Ruang Wilayah Kabupaten (RTRWK) Kabupaten Tuban, Provinsi Jawa Timur.

\section{METODE PENELITIAN}

Penelitian dilakukan di Kabupaten Tuban, Provinsi Jawa Timur. Wilayah ini secara geografis terletak pada $111^{\circ} 30^{\prime}-112^{\circ} 35^{\prime} \mathrm{BT}$ dan $6^{\circ} 40^{\prime}$ 7¹8'LS. Berdasarkan data iklim 2004-2013, wilayah penelitian memiliki iklim tropika basah dengan curah hujan tahunan rata-rata $2.132,7 \mathrm{~mm}$, curah hujan bulanan berkisar antara $2,1 \mathrm{~mm}$ sampai dengan 430,2 $\mathrm{mm}$. Temperatur rata-rata bulanan berkisar antara 26,6 sampai $28,9^{\circ} \mathrm{C}$.

Ketinggian daratan di Kabupaten Tuban berkisar antara 0 sampai 500 meter dari permukaan laut (d.p.l.). Bagian utara dan selatan wilayah merupakan dataran rendah dengan ketinggian 0 sampai 50 meter d.p.l. yang terdapat di sekitar pantai dan sepanjang Sungai Bengawan Solo.
Daerah yang memiliki ketinggian di atas 100 meter d.p.l. terdapat di bagian tengah wilayah.

Penggunaan lahan dan tutupan lahan didelineasi menggunakan citra Landsat OLI tahun liputan 2013. Interpretasi citra dilakukan dengan klasifikasi terbimbing, diikuti dengan pengecekan lapang. Interpretasi dilakukan menggunakan perangkat lunak ERDAS Imagine. Analisis penggunaan lahan dan tutupan lahan menghasilkan 10 jenis penggunaan dan tutupan lahan sesuai dengan standar nasional penutupan lahan (Anonim, 2010a).

Survai tanah dan evaluasi lahan di wilayah studi dilakukan pada tahun 2014 atas prakarsa Badan Perencanaan Pembangunan Daerah Kabupaten Tuban. Dalam survai ini, dilakukan pengamatan morfologi tanah dan sampling untuk analisis di laboratorium untuk pemetaan dan evaluasi lahan. Dalam analisis kemampuan lahan ini, hasil analisis laboratorium yang digunakan hanya tekstur tanah.

Satuan Peta Lahan (SPL) dibentuk dari unsur SPL yang terdiri dari jenis tanah sampai kategori sub-group (Anonim, 2010b), bentuk wilayah, bahan induk dan kemiringan lereng. Pembuatan SPL dilakukan dengan bantuan Peta Satuan Tanah dan Lahan skala 1:250.000 (Anonim, 2011), didetilkan dengan satuan lereng dari Peta Rupa Bumi Indonesia (RBI) skala 1:25.000, sampling tanah dan survai lapangan. Seluruh wilayah Tuban tercakup dalam 39 SPL. Evaluasi kemampuan lahan dilakukan terhadap SPL ini. Pada Gambar 1, disajikan distribusi spasial SPL dengan pembedaan warna hanya berdasarkan jenis tanahnya atau hanya salah satu unsur SPL, inipun disederhanakan hanya sampai kategori ordo untuk alasan kejelasan gambar.

Dari gambar tersebut terlihat bahwa terdapat 5 (lima) ordo tanah, yaitu Inceptisol, Alfisol, Vertisol, Ultisol dan Entisol. Ordo Inceptisol menempati areal terluas, meliputi 83.120 ha, atau $45,2 \%$ wilayah. Tanah lain yang juga cukup luas penyebarannya adalah Alfisol, yang arealnya meliputi 41.913 ha atau 22,8\%. Dominansi tanah Inceptisol dan Alfisol berkaitan dengan perkembangan tanah dan iklim setempat. Tanahtanah Inceptisol merupakan tanah yang relatif muda dan belum berkembang terlalu lanjut, dicirikan oleh adanya horizon kambik. Tanah Alfisol dicirikan oleh horizon penimbunan liat (argilik) dan mempunyai kejenuhan basa tinggi $(>35 \%)$. Perkembangan tanah-tanah dominan di Tuban ini berkaitan dengan bahan induk yang relatif basa dan berkapur (Tan, 2009).

Analisis kemampuan lahan dilakukan sesuai dengan metoda yang dideskripsi dalam Arsyad 


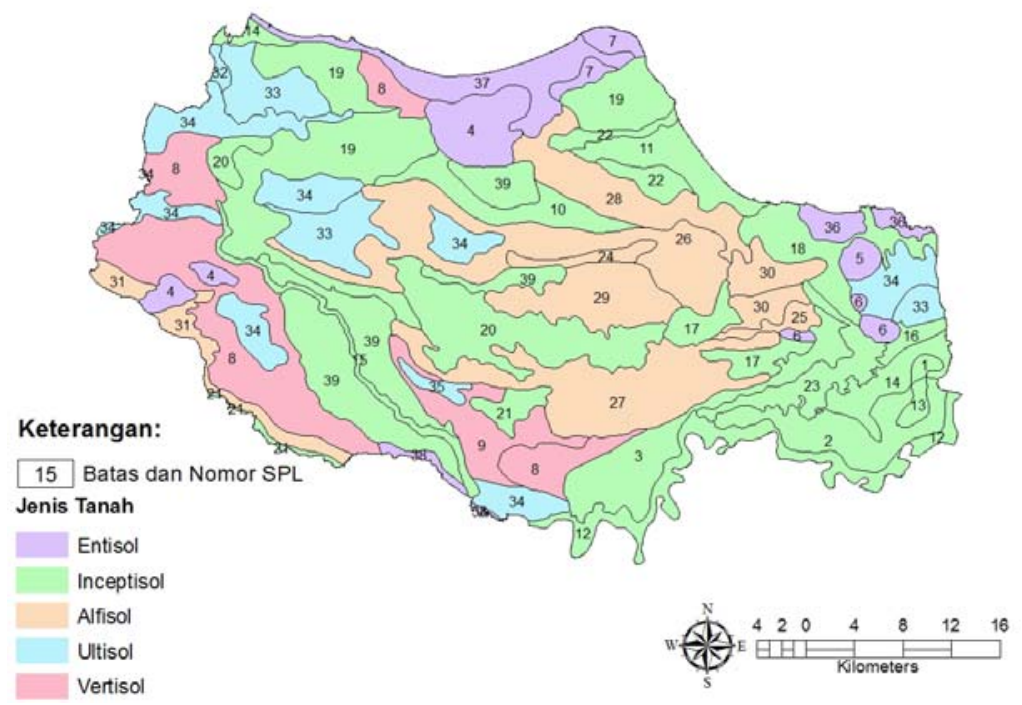

Gambar 1. Satuan Peta Lahan (SPL), jenis tanah sampai kategori ordo di wilayah Kabupaten Tuban.

Tabel 1. Kriteria kuantitatif kemampuan lahan dan faktor pembatas.

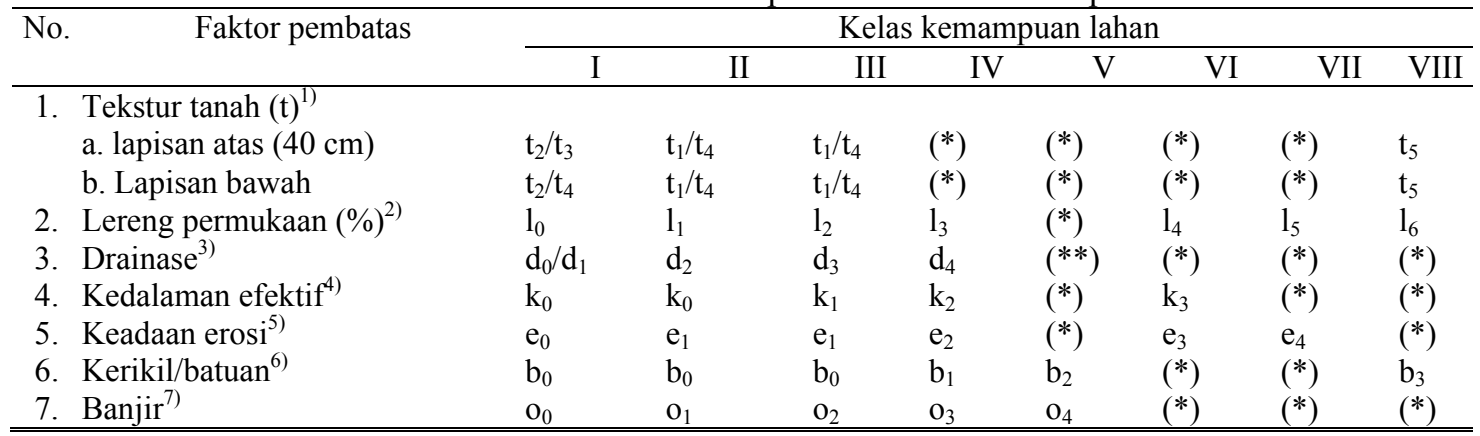

Sumber: Arsyad (2010, dengan modifikasi); Hardjowigeno dan Widiatmaka (2007)

Keterangan:

$\left(^{*}\right)$ : dapat mempunyai sembarang sifat faktor penghambat dari kelas yang lebih rendah

$(* *)$ : permukaan tanah selalu tergenang air

1) Tekstur: $t_{1}$ : halus; $t_{2:}$ agak halus; $t_{3}$ : sedang; $t_{4}$ : agak kasar; $t_{5}($ kasar);

${ }^{2)}$ Lereng permukaan: $1_{0:}\left(0-3 \% ; 1_{1}(3-8 \%) ; 1_{2}(8-15 \%) ; 1_{3}(15-30 \%) ; 1_{4}(30-45 \%) ; 1_{5}(45-65 \%) ; 1_{6}(>65 \%)\right.$;

${ }^{3)}$ Drainase: $d_{0}$ (baik): $d_{1}$ (agak baik); $d_{2}$ (agak buruk); $d_{3}$ (buruk); $d_{4}$ (sangat buruk)

${ }^{4)}$ Kedalaman efektif: $\mathrm{k}_{0}$ (dalam); $\mathrm{k}_{1}$ (sedang); $\mathrm{k}_{2}$ (dangkal); $\mathrm{k}_{3}$ (sangat dangkal);

${ }^{5)}$ Keadaan erosi: $\mathrm{e}_{0}$ (tidak ada erosi); $\mathrm{e}_{1}$ (ringan); $\mathrm{e}_{2}$ (sedang); $\mathrm{e}_{3}$ (berat); $\mathrm{e}_{4}$ (sangat berat).

${ }^{6)}$ Kerikil/batuan: $b_{0}$ : tidak ada atau sedikit $b_{1}$ :sedang; $b_{2}$ : banyak; $b_{3}$ :sangat banyak

${ }^{7)}$ Banjir: $\mathrm{o}_{0}$ : tidak pernah; $\mathrm{o}_{1}$ : jarang; $\mathrm{o}_{2}$ : kadang-kadang; $\mathrm{o}_{3}$ : sering; $\mathrm{o}_{4}$ : sangat sering.

Tabel 2. Kriteria penggunaan lahan yang diperkenankan pada setiap kelas kemampuan lahan.

\begin{tabular}{lll}
\hline No. & Kemampuan lahan & Penggunaan lahan yang diperkenankan \\
\hline 1 & I & Semua jenis penggunaan lahan \\
2 & II & Semua jenis penggunaan lahan kecuali Psi \\
3 & III & Semua jenis penggunaan lahan kecuali Psi dan Pi (hanya Psd) \\
4 & IV & Pt, semua jenis penggembalaan, semua jenis hutan \\
5 & V & Semua jenis penggembalaan (Pgi, Pgsd, Pgt), semua jenis hutan \\
6 & VI & Pgsd, Pgt, semua jenis hutan \\
7 & VII & Pgt, hutan \\
8 & VIII & Cagar alam dan hutan lindung \\
\hline
\end{tabular}

Sumber: Klingebiel dan Montgomery (1961, diringkas) dan Fenton (2014)

Keterangan: Psi: Pertanian sangat intensif; Pi: Pertanian intensif; Psd: pertanian intensitas sedang; Pt: Pertanian terbatas; Pgi: penggembalaan intensif; Pgsd: penggembalaan sedang; Pgt: Penggembalaan terbatas.

(2010) dan Hardjowigeno dan Widiatmaka (2007). Karakteristik lahan penciri dalam klasifikasi kemampuan lahan yang digunakan adalah faktor penghambat yang bersifat permanen atau sulit dapat diubah yaitu tekstur tanah, lereng permukaan, drainase, kedalaman efektif tanah, tingkat erosi yang terjadi, batuan di permukaan tanah, dan ancaman banjir atau genangan air yang tetap. Faktor-faktor tersebut digolongkan berdasarkan besarnya intensitas penghambatan atau ancaman 
(Arsyad, 2010). Kriteria yang digunakan disajikan pada Tabel 1. Penggunaan lahan yang diperbolehkan pada setiap kelas kemampuan lahan mengacu pada Klingebiel dan Montgomery (1961) dan Fenton (2014), disajikan pada Tabel 2.

Hasil analisis kemampuan lahan kemudian dibandingkan dengan penggunaan lahan aktual hasil interpretasi citra Landsat 8 OLI dan alokasi pola ruang dalam Rencana Tata Ruang Wilayah Kabupaten (RTRWK). Dalam RTRWK, pola ruang merupakan acuan untuk alokasi pemanfaatan lahan (Undang-undang Nomor 26 Tahun 2007). Kesesuaian antara kemampuan lahan dengan penggunaan lahan aktual dan alokasi dalam pola ruang dikelaskan dalam 3 (tiga) kategori: sesuai, sesuai bersyarat, dan tidak sesuai. Kesesuaian yang digolongkan "sesuai", berarti penggunaan lahan aktual atau alokasi pola ruang dalam RTRWK telah sesuai dengan kemampuan lahannya. Demikian pula sebaliknya, kesesuaian yang digolongkan "tidak sesuai", berarti penggunaan lahan aktual atau alokasi dalam pola ruang dalam RTRWK melebihi daya dukung berbasis kemampuan lahannya. Sementara itu, kesesuaian digolongkan "sesuai bersyarat", jika penggunaan lahan aktual atau alokasi lahan dalam pola ruang pada RTRWK melebihi daya dukung berbasis kemampuan lahannya, namun penggunaan lahan aktual atau alokasi tersebut masih dimungkinkan, asalkan diberikan perlakuan untuk menghilangkan faktor pembatas kemampuan lahannya. Dalam evaluasi ini, tubuh air tidak dinilai kesesuaiannya. Dalam hal kelas kemampuan lahan, lahan kelas I sampai kelas IV merupakan lahan yang diperkenankan untuk budidaya (Fenton, 2014) dan dalam makalah ini secara umum disebut lahan dengan kelas kemampuan lahan tinggi sampai cukup. Lahan kelas V sampai kelas VIII merupakan lahan dengan kemampuan terbatas dan harus dilindungi, dalam makalah ini secara umum disebut lahan dengan kelas kemampuan agak rendah sampai rendah

\section{HASIL DAN PEMBAHASAN}

Penggunaan lahan dan tutupan lahan aktual hasil interpretasi citra Landsat 8 OLI disajikan pada Gambar 2 dan Tabel 3. Penggunaan lahan utama di Tuban ditinjau dari sisi luas, berturut-turut adalah lahan pertanian, hutan, tanah terbuka, belukar dan sawah. Lahan kering juga menempati areal yang cukup luas, demikian pula pemukiman. Penggunaan lahan lain (tambak dan badan air) relatif sedikit.

Hasil penilaian kemampuan lahan pada setiap SPL disajikan pada Tabel 4. Rekapitulasinya disajikan pada Tabel 5 dan Tabel 6, sedangkan penyajiannya dalam bentuk spasial disajikan pada Gambar 3.
Di Tuban, tidak ada lahan kelas I. Lahan kelas I merupakan lahan yang sesuai untuk segala jenis penggunaan lahan tanpa memerlukan tindakan pengawetan tanah yang khusus (Arsyad, 2010; Fenton, 2014). Lahan terbaik yang ditemukan di Tuban adalah lahan kelas II, yaitu lahan dengan penghambat yang relatif sedikit. Lahan kelas II di Tuban dijumpai seluas 55.090 ha atau 30\% luas wilayah. Penghambat yang dijumpai pada lahan kelas II di Tuban adalah lereng, drainase, tekstur dan banjir/genangan.

Lahan kelas III dijumpai pada areal seluas 81.606 ha atau $44 \%$ dari luas wilayah Kabupaten Tuban yang seluas 183.995 ha. Lahan kelas III mempunyai penghambat yang agak berat, yang mengurangi pilihan jenis penggunaan yang dapat diusahakan, atau memerlukan usaha pengawetan tanah yang khusus, atau keduanya. Di Tuban, penghambat utama yang mengantarkan lahan ke kelas III adalah lereng, drainase, bahaya banjir/genangan dan kedalaman efektif.

Lahan dengan kelas kemampuan lahan IV menempati luas 7.860 ha di Kabupaten Tuban atau $4,3 \%$ dari luas wilayah. Lahan kelas IV mempunyai penghambat yang berat yang membatasi pilihan penggunaan lahan, memerlukan pengelolaan yang harus dilakukan dengan sangat hati-hati, atau kedua-duanya (Klingebiel dan Montgomery, 1961; Arsyad, 2010; Fenton, 2014). Penggunaan lahan kelas IV sangat terbatas karena salah satu atau kombinasi dari penghambat seperti lereng yang curam, kepekaan erosi yang besar, erosi yang telah tejadi berat, tanah dangkal, daya menahan air rendah, sering tergenang banjir yang menimbulkan kerusakan berat pada tanaman, dan drainase terhambat dan masih sering tergenang meskipun telah dibuat saluran drainase (Klingebiel dan Montgomery, 1961; Arsyad, 2010; Fenton, 2014). Dalam hal lahan di Tuban, hambatan utama yang mengantarkan lahan ke kelas kemampuan lahan IV adalah lereng.

Tabel 3. Luas penggunaan dan tutupan lahan wilayah penelitian Tuban.

\begin{tabular}{llrr}
\hline \multirow{2}{*}{ No } & \multirow{2}{*}{ Penggunaan /tutupan lahan } & \multicolumn{2}{c}{ Luas } \\
\cline { 3 - 4 } & & \multicolumn{1}{c}{ ha } & \multicolumn{1}{c}{$\%$} \\
\hline 1 & Awan & $2.171,1$ & 1,2 \\
2 & Badan air & 864,8 & 0,5 \\
3 & Hutan & $37.001,3$ & 20,1 \\
4 & Lahan kering & $19.356,2$ & 10,5 \\
5 & Lahan pertanian & $37.829,3$ & 20,6 \\
6 & Permukiman & $11.260,5$ & 6,1 \\
7 & Sawah & $21.104,2$ & 11,5 \\
8 & Semak belukar & $21.858,6$ & 11,9 \\
9 & Tambak & 956,8 & 0,5 \\
10 & Tanah terbuka & $31.591,9$ & 17,2 \\
\hline & Total & $183.994,6$ & 100,0 \\
\hline
\end{tabular}




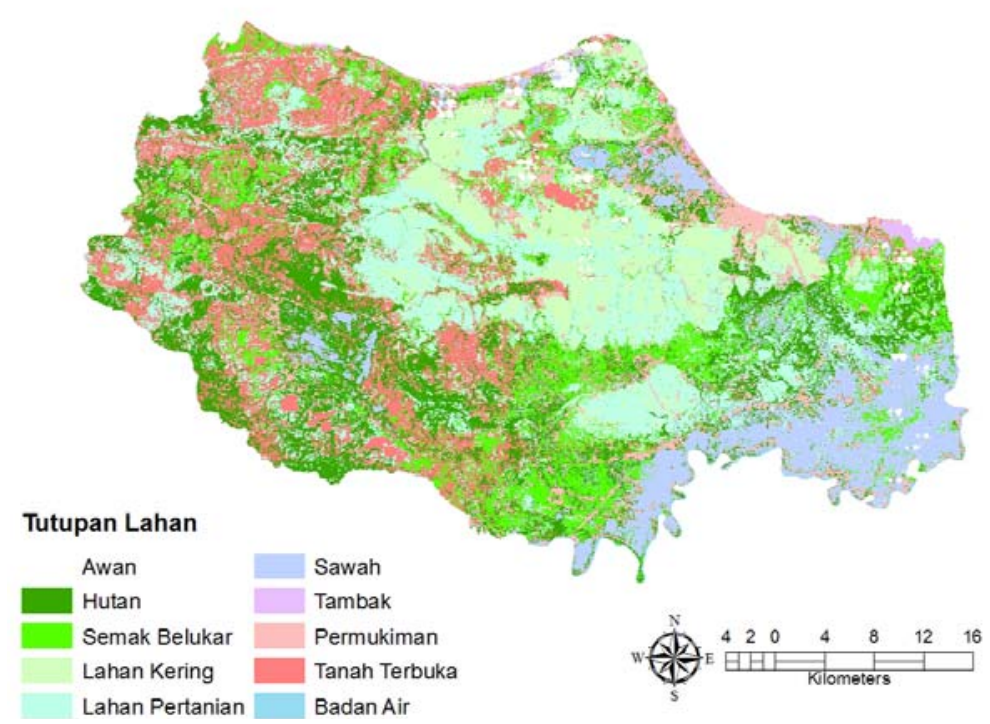

Gambar 2. Penggunaan dan tutupan lahan wilayah penelitian Tuban.

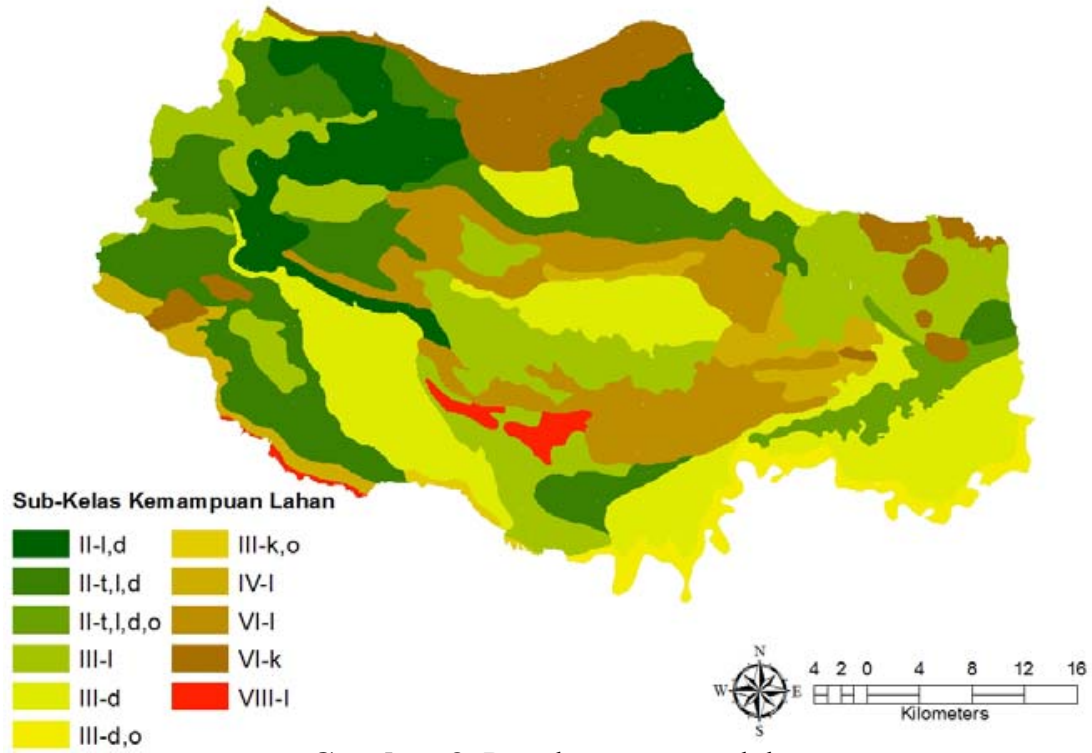

Gambar 3. Peta kemampuan lahan.

Lahan kelas VI mempunyai penghambat yang sangat berat sehingga tidak sesuai untuk pertanian dan hanya sesuai untuk tanaman rumput ternak atau dihutankan (Klingebiel dan Montgomery, 1961; Arsyad, 2010; Fenton, 2014). Lahan kelas VI menempati areal seluas $37.268,4$ ha atau $20,2 \%$ dari luas wilayah. Penggunaan untuk padang rumput harus dijaga agar rumputnya selalu menutup dengan baik. Bila dihutankan, penebangan kayu harus selektif. Lahan ini mempunyai penghambat yang sangat sulit diperbaiki. Di Tuban, penghambat utama yang mengantarkan lahan ke kelas VI adalah lereng, yaitu kemiringan antara $30-45 \%$, atau kedalaman efektif. Berdasarkan hasil pemetaan dan kunjungan lapang, porsi terbesar adalah pada faktor lereng.

Lahan kelas VIII menempati areal seluas $2.170,8$ ha atau $1,2 \%$ luas wilayah. Faktor penghambat utamanya adalah lereng, terutama lereng $>40 \%$. Lahan kelas VIII tidak sesuai untuk produksi pertanian, dan harus dibiarkan dalam keadaan alami atau dibawah vegetasi hutan (Klingebiel dan Montgomery, 1961; Arsyad, 2010; Fenton, 2014). Lahan ini dapat digunakan untuk rekreasi, cagar alam atau hutan lindung.

Hasil rekapitulasi kemampuan lahan di Kabupaten Tuban secara keseluruhan berdasarkan kelas dan faktor penghambatnya (Tabel 5 dan 6), menunjukkan bahwa penghambat utama lahan dari sisi luas adalah lereng, diikuti oleh drainase, tekstur lapisan atas, atau kombinasi diantara ketiganya. Dengan demikian, upaya yang perlu dilakukan di Tuban adalah upaya-upaya konservasi yang sifatnya pencegahan erosi dan perbaikan drainase.

Hasil analisis kesesuaian antara kemampuan lahan dengan penggunaan lahan aktual di seluruh wilayah Tuban disajikan pada Gambar 4 dan Tabel 7. Rekapitulasi perhitungan secara lebih garis besar disajikan pada Tabel 8. Dari tabel dan gambar tersebut, terlihat bahwa pada lahan-lahan berke- 
Tabel 4. Kemampuan lahan dan faktor pembatas utama pada masing-masing SPL Kabupaten Tuban.

\begin{tabular}{|c|c|c|c|c|c|c|c|c|c|c|c|}
\hline \multirow{2}{*}{ SPL } & \multicolumn{8}{|c|}{ Faktor pembatas } & \multirow{2}{*}{$\mathrm{KKL}^{1)}$} & \multirow{2}{*}{ Pembatas utama ${ }^{2)}$} & \multirow{2}{*}{$\begin{array}{l}\text { Luas } \\
\text { (ha) }\end{array}$} \\
\hline & TLA & TLB & LRG & DRA & KEF & KER & $\mathrm{KB}$ & BJR & & & \\
\hline 1 & $\mathrm{t}_{1}$ & $\mathrm{t}_{2}$ & $1_{0}$ & $\mathrm{~d}_{2}$ & $\mathrm{k}_{0}$ & $\mathrm{e}_{0}$ & $\mathrm{~b}_{0}$ & $\mathrm{O}_{1}$ & III-d & DRA & 349,8 \\
\hline 2 & $t_{1}$ & $t_{2}$ & $1_{0}$ & $\mathrm{~d}_{2}$ & $\mathrm{k}_{0}$ & $\mathrm{e}_{0}$ & $\mathrm{~b}_{0}$ & $\mathrm{o}_{1}$ & III-d & DRA & $5.200,8$ \\
\hline 3 & $\mathrm{t}_{1}$ & $t_{2}$ & $1_{0}$ & $\mathrm{~d}_{2}$ & $\mathrm{k}_{0}$ & $\mathrm{e}_{0}$ & $\mathrm{~b}_{0}$ & $\mathrm{o}_{1}$ & III-d & DRA & $6.202,5$ \\
\hline 4 & $\mathrm{t}_{4}$ & $t_{4}$ & $1_{3}$ & $\mathrm{~d}_{0}$ & $\mathrm{k}_{3}$ & $\mathrm{e}_{1}$ & $b_{1}$ & $\mathrm{o}_{0}$ & VI-k & $\mathrm{KEF}$ & $5.099,5$ \\
\hline 5 & $t_{4}$ & $t_{4}$ & $1_{3}$ & $\mathrm{~d}_{0}$ & $\mathrm{k}_{3}$ & $e_{1}$ & $b_{1}$ & $\mathrm{o}_{0}$ & VI-k & KEF & 852,4 \\
\hline 6 & $\mathrm{t}_{4}$ & $\mathrm{t}_{4}$ & $1_{4}$ & $\mathrm{~d}_{0}$ & $\mathrm{k}_{3}$ & $\mathrm{e}_{1}$ & $b_{1}$ & $\mathrm{o}_{0}$ & VI-k & KEF & 871,7 \\
\hline 7 & $t_{4}$ & $\mathrm{t}_{4}$ & $1_{1}$ & $\mathrm{~d}_{1}$ & $\mathrm{k}_{3}$ & $\mathrm{e}_{0}$ & $b_{1}$ & $\mathrm{o}_{0}$ & VI-k & $\mathrm{KEF}$ & $1.387,0$ \\
\hline 8 & $t_{1}$ & $\mathrm{t}_{1}$ & $1_{1}$ & $\mathrm{~d}_{1}$ & $\mathrm{k}_{0}$ & $\mathrm{e}_{0}$ & $\mathrm{~b}_{0}$ & $\mathrm{o}_{0}$ & II-t,l,d & TLA, LRG, DRA & $17.855,5$ \\
\hline 9 & $t_{1}$ & $\mathrm{t}_{1}$ & $1_{2}$ & $\mathrm{~d}_{0}$ & $\mathrm{k}_{0}$ & $\mathrm{e}_{1}$ & $\mathrm{~b}_{0}$ & $\mathrm{o}_{0}$ & III-1 & LRG & $4.366,8$ \\
\hline 10 & $t_{1}$ & $t_{2}$ & $1_{1}$ & $\mathrm{~d}_{1}$ & $\mathrm{k}_{0}$ & $\mathrm{e}_{0}$ & $\mathrm{~b}_{0}$ & $\mathrm{o}_{0}$ & II-t, $1, d$ & TLA, LRG, DRA & $3.510,3$ \\
\hline 11 & $t_{1}$ & $t_{2}$ & $1_{0}$ & $\mathrm{~d}_{2}$ & $\mathrm{k}_{0}$ & $\mathrm{e}_{0}$ & $\mathrm{~b}_{0}$ & $\mathrm{o}_{1}$ & III-d & DRA & $3.519,3$ \\
\hline 12 & $t_{1}$ & $t_{2}$ & $1_{0}$ & $\mathrm{~d}_{2}$ & $\mathrm{k}_{0}$ & $\mathrm{e}_{0}$ & $\mathrm{~b}_{0}$ & $\mathrm{O}_{2}$ & III-d,o & DRA, BJR & $5.295,6$ \\
\hline 13 & $t_{1}$ & $t_{2}$ & $1_{0}$ & $\mathrm{~d}_{2}$ & $\mathrm{k}_{0}$ & $\mathrm{e}_{0}$ & $\mathrm{~b}_{0}$ & $\mathrm{o}_{1}$ & III-d & DRA & 574,6 \\
\hline 14 & $t_{1}$ & $t_{2}$ & $1_{0}$ & $\mathrm{~d}_{2}$ & $\mathrm{k}_{0}$ & $\mathrm{e}_{0}$ & $\mathrm{~b}_{0}$ & $\mathrm{o}_{1}$ & III-d & DRA & $3.190,1$ \\
\hline 15 & $t_{1}$ & $t_{2}$ & $1_{0}$ & $\mathrm{~d}_{2}$ & $\mathrm{k}_{0}$ & $\mathrm{e}_{0}$ & $\mathrm{~b}_{0}$ & $\mathrm{o}_{1}$ & III-d & DRA & $1.760,3$ \\
\hline 16 & $\mathrm{t}_{1}$ & $t_{2}$ & $1_{1}$ & $\mathrm{~d}_{1}$ & $\mathrm{k}_{0}$ & $\mathrm{e}_{0}$ & $\mathrm{~b}_{0}$ & $\mathrm{o}_{1}$ & II-t,1,d,o & TLA, LRG, DRA, BJR & 744,0 \\
\hline 17 & $\mathrm{t}_{1}$ & $t_{2}$ & $1_{3}$ & $\mathrm{~d}_{0}$ & $\mathrm{k}_{0}$ & $\mathrm{e}_{1}$ & $\mathrm{~b}_{0}$ & $\mathrm{o}_{0}$ & IV-1 & LRG & $2.798,5$ \\
\hline 18 & $t_{1}$ & $t_{2}$ & $1_{2}$ & $\mathrm{~d}_{0}$ & $\mathrm{k}_{0}$ & $\mathrm{e}_{1}$ & $\mathrm{~b}_{0}$ & $\mathrm{o}_{0}$ & III-1 & LRG & $4.298,3$ \\
\hline 19 & $t_{1}$ & $t_{2}$ & $1_{1}$ & $\mathrm{~d}_{1}$ & $\mathrm{k}_{0}$ & $\mathrm{e}_{0}$ & $\mathrm{~b}_{0}$ & $\mathrm{o}_{0}$ & II-1,d & LRG, DRA & $16.190,6$ \\
\hline 20 & $\mathrm{t}_{1}$ & $t_{2}$ & $1_{2}$ & $\mathrm{~d}_{0}$ & $\mathrm{k}_{0}$ & $\mathrm{e}_{1}$ & $\mathrm{~b}_{0}$ & $\mathrm{o}_{0}$ & III-1 & LRG & $9.548,9$ \\
\hline 21 & $\mathrm{t}_{1}$ & $t_{2}$ & $1_{5}$ & $\mathrm{~d}_{0}$ & $\mathrm{k}_{0}$ & $\mathrm{e}_{2}$ & $\mathrm{~b}_{0}$ & $\mathrm{o}_{0}$ & VIII-1 & LRG & $1.566,3$ \\
\hline 22 & $t_{1}$ & $t_{2}$ & $1_{0}$ & $\mathrm{~d}_{2}$ & $\mathrm{k}_{0}$ & $\mathrm{e}_{0}$ & $\mathrm{~b}_{0}$ & $\mathrm{o}_{1}$ & III-d & DRA & $2.132,1$ \\
\hline 23 & $t_{1}$ & $t_{2}$ & $1_{1}$ & $\mathrm{~d}_{1}$ & $\mathrm{k}_{0}$ & $\mathrm{e}_{0}$ & $\mathrm{~b}_{0}$ & $\mathrm{o}_{1}$ & II-t,l,d,o & TLA, LRG, DRA, BJR & $3.495,6$ \\
\hline 24 & $t_{1}$ & $t_{1}$ & $1_{3}$ & $\mathrm{~d}_{0}$ & $\mathrm{k}_{0}$ & $\mathrm{e}_{1}$ & $\mathrm{~b}_{0}$ & $\mathrm{o}_{0}$ & IV-1 & LRG & $1.043,7$ \\
\hline 25 & $\mathrm{t}_{1}$ & $t_{1}$ & $1_{3}$ & $\mathrm{~d}_{0}$ & $\mathrm{k}_{0}$ & $e_{1}$ & $\mathrm{~b}_{0}$ & $\mathrm{o}_{0}$ & IV-1 & LRG & 918,2 \\
\hline 26 & $t_{1}$ & $\mathrm{t}_{1}$ & $1_{4}$ & $\mathrm{~d}_{0}$ & $\mathrm{k}_{0}$ & $\mathrm{e}_{1}$ & $\mathrm{~b}_{0}$ & $\mathrm{o}_{0}$ & VI-1 & LRG & $11.751,0$ \\
\hline 27 & $\mathrm{t}_{1}$ & $\mathrm{t}_{1}$ & $1_{4}$ & $\mathrm{~d}_{0}$ & $\mathrm{k}_{0}$ & $\mathrm{e}_{1}$ & $\mathrm{~b}_{0}$ & $\mathrm{o}_{0}$ & VI-1 & LRG & $10.749,0$ \\
\hline 28 & $t_{1}$ & $t_{1}$ & $1_{1}$ & $\mathrm{~d}_{1}$ & $\mathrm{k}_{0}$ & $\mathrm{e}_{0}$ & $\mathrm{~b}_{0}$ & $\mathrm{o}_{0}$ & II-t,l,d & TLA, LRG, DRA & $5.874,3$ \\
\hline 29 & $t_{1}$ & $t_{1}$ & $1_{2}$ & $\mathrm{~d}_{0}$ & $\mathrm{k}_{0}$ & $\mathrm{e}_{1}$ & $\mathrm{~b}_{0}$ & $\mathrm{o}_{0}$ & III-d & DRA & $5.272,9$ \\
\hline 30 & $t_{1}$ & $t_{1}$ & $1_{2}$ & $\mathrm{~d}_{0}$ & $\mathrm{k}_{0}$ & $\mathrm{e}_{1}$ & $\mathrm{~b}_{0}$ & $\mathrm{o}_{0}$ & III-1 & LRG & $3.257,7$ \\
\hline 31 & $t_{1}$ & $\mathrm{t}_{1}$ & $1_{3}$ & $\mathrm{~d}_{0}$ & $\mathrm{k}_{0}$ & $\mathrm{e}_{1}$ & $\mathrm{~b}_{0}$ & $\mathrm{o}_{0}$ & IV-1 & LRG & $3.099,9$ \\
\hline 32 & $t_{2}$ & $t_{1}$ & $1_{0}$ & $\mathrm{~d}_{2}$ & $\mathrm{k}_{0}$ & $\mathrm{e}_{0}$ & $\mathrm{~b}_{0}$ & $\mathrm{o}_{0}$ & III-d & DRA & 347,1 \\
\hline 33 & $t_{2}$ & $\mathrm{t}_{1}$ & $1_{1}$ & $\mathrm{~d}_{1}$ & $\mathrm{k}_{0}$ & $\mathrm{e}_{0}$ & $\mathrm{~b}_{0}$ & $\mathrm{o}_{0}$ & II-t, $1, d$ & TLA, LRG, DRA & $7.419,1$ \\
\hline 34 & $t_{2}$ & $\mathrm{t}_{1}$ & $1_{2}$ & $\mathrm{~d}_{0}$ & $\mathrm{k}_{0}$ & $\mathrm{e}_{1}$ & $\mathrm{~b}_{0}$ & $\mathrm{o}_{0}$ & III-1 & LRG & $12.912,7$ \\
\hline 35 & $t_{2}$ & $t_{1}$ & $1_{5}$ & $\mathrm{~d}_{0}$ & $\mathrm{k}_{0}$ & $\mathrm{e}_{2}$ & $\mathrm{~b}_{0}$ & $\mathrm{o}_{0}$ & VIII-1 & LRG & 604,5 \\
\hline 36 & $\mathrm{t}_{4}$ & $\mathrm{t}_{4}$ & $1_{2}$ & $\mathrm{~d}_{0}$ & $\mathrm{k}_{3}$ & $\mathrm{e}_{1}$ & $\mathrm{~b}_{0}$ & $\mathrm{o}_{0}$ & VI-k & $\mathrm{KEF}$ & $1.615,5$ \\
\hline 37 & $\mathrm{t}_{4}$ & $\mathrm{t}_{4}$ & $1_{0}$ & $\mathrm{~d}_{0}$ & $\mathrm{k}_{3}$ & $\mathrm{e}_{0}$ & $\mathrm{~b}_{0}$ & $\mathrm{o}_{0}$ & VI-k & KEF & $4.942,4$ \\
\hline 38 & $\mathrm{t}_{4}$ & $\mathrm{t}_{4}$ & $1_{0}$ & $\mathrm{~d}_{0}$ & $\mathrm{k}_{2}$ & $\mathrm{e}_{0}$ & $\mathrm{~b}_{0}$ & $\mathrm{O}_{2}$ & III-k,o & KEF, BJR & 598,0 \\
\hline 39 & $\mathrm{t}_{1}$ & $\mathrm{t}_{2}$ & $1_{0}$ & $\mathrm{~d}_{2}$ & $\mathrm{k}_{0}$ & $\mathrm{e}_{0}$ & $\mathrm{~b}_{0}$ & $\mathrm{o}_{1}$ & III-d & DRA & $12.778,3$ \\
\hline
\end{tabular}

Keterangan: ${ }^{11} \mathrm{KKL}$ : Kelas kemampuan lahan; ${ }^{2}$ TLA: tekstur lapisan atas; TLB: tekstur lapisan bawah; LRG: lereng; DRA: drainase; KEF: kedalaman efektif; KB: kerikil/batuan; BJR: banjir.

Tabel 5. Rekapitulasi pengelompokan lahan di Tuban berdasarkan kemampuan lahan.

\begin{tabular}{llllrr}
\hline \multirow{2}{*}{ No } & \multicolumn{2}{c}{$\begin{array}{c}\text { Kemampuan } \\
\text { lahan }\end{array}$} & & \multicolumn{2}{c}{ Luas } \\
\cline { 2 - 3 } \cline { 5 - 6 } & Kelas & Sub Kelas & & ha & \multicolumn{1}{c}{$\%$} \\
\hline 1 & II & II-l,d & & $16.190,6$ & 8,8 \\
& & II-t,1,d & & $34.659,7$ & 18,8 \\
& & II-t,1,d,o & & $4.239,6$ & 2,3 \\
2 & \multirow{2}{*}{ III } & III-l & & $34.384,3$ & 18,7 \\
& & III-d & & $41.327,8$ & 22,5 \\
& & III-d,o & & $5.295,6$ & 2,9 \\
& & III-k,o & & 598,0 & 0,3 \\
3 & IV & IV-1 & & $7.860,3$ & 4,3 \\
4 & VI & VI-k & & $14.768,4$ & 8,0 \\
& & VI-l & & $22.500,0$ & 12,2 \\
5 & VIII & VIII-1 & & $2.170,8$ & 1,2 \\
\hline & Total & & & $183.994,6$ & 100,0 \\
\hline
\end{tabular}

Tabel 6. Rekapitulasi pengelompokan lahan di Tuban berdasarkan faktor pembatas kemampuan lahan.

\begin{tabular}{llrr}
\hline \multirow{2}{*}{ No } & \multicolumn{2}{c}{ Faktor pembatas } & \multicolumn{2}{c}{ Luas } \\
\cline { 3 - 4 } & kemampuan lahan & ha & \multicolumn{1}{c}{$\%$} \\
\hline 1 & LRG & $66.915,4$ & 36,4 \\
2 & DRA & $41.327,8$ & 22,5 \\
3 & KEF & $14.768,4$ & 8,0 \\
4 & LRG DRA & $16.190,6$ & 8,8 \\
5 & DRA BJR & $5.295,6$ & 2,9 \\
6 & KEF BJR & 598,0 & 0,3 \\
7 & TLA LRG DRA & $34.659,7$ & 18,8 \\
8 & TLA LRG DRA BJR & $4.239,6$ & 2,3 \\
\hline & Total & $183.994,6$ & 100,0 \\
\hline
\end{tabular}

Keterangan: TLA: tekstur lapisan atas; TLB: tekstur lapisan bawah; LRG: lereng; DRA: drainase; KEF: kedalaman efektif; KB: kerikil/batuan; BJR: banjir. 


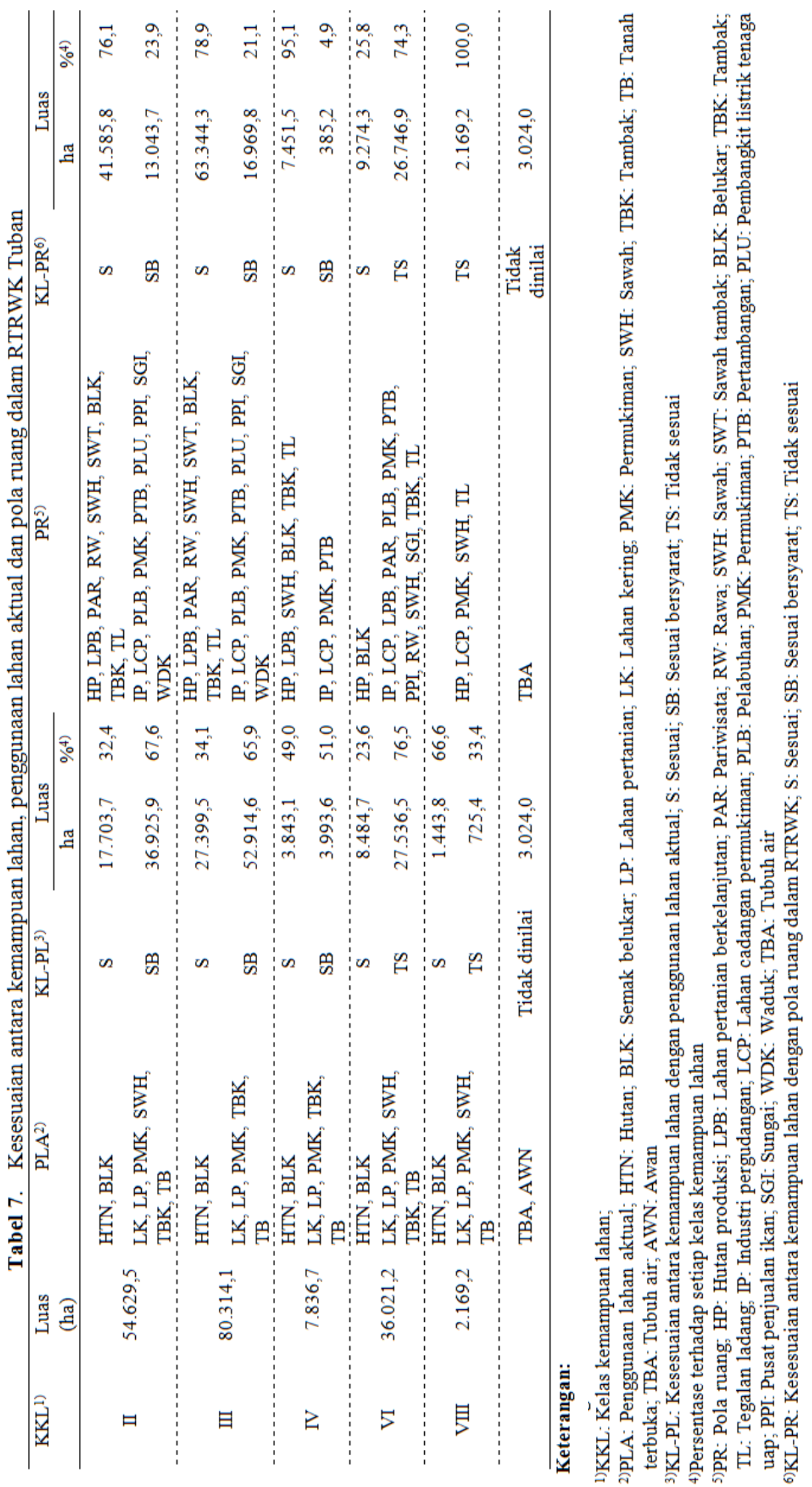


Tabel 8. Rekapitulasi perhitungan kesesuaian antara kemampuan lahan dengan penggunaan lahan saat ini, dan dengan rencana pola ruang dalam RTRW Kabupaten.

\begin{tabular}{|c|c|c|c|c|c|}
\hline No & $\mathrm{KKL}^{1)}$ & Luas KL-PL ${ }^{2)}$ (ha) & $\%$ & Luas KL-PR ${ }^{3)}$ (ha) & $\%$ \\
\hline \multirow[t]{5}{*}{1.} & \multicolumn{5}{|c|}{ Lahan berkemampuan tinggi sampai sedang (I-IV) } \\
\hline & $\mathrm{S}$ & $48.946,2$ & 34,3 & $112.381,7$ & 78,7 \\
\hline & SB & $93.834,1$ & 65,7 & $30.398,6$ & 21,3 \\
\hline & \multicolumn{5}{|l|}{ TS } \\
\hline & Jumlah & $142.780,3$ & 100,0 & $142.780,3$ & 100,0 \\
\hline \multirow[t]{5}{*}{2.} & \multicolumn{5}{|c|}{ Lahan berkemampuan agak rendah sampai rendah (V-VIII) } \\
\hline & $\mathrm{S}$ & $9.928,4$ & 26,0 & $11.443,5$ & 30,0 \\
\hline & SB & - & - & - & . \\
\hline & TS & $28.261,9$ & 74,0 & $26.746,9$ & 70,0 \\
\hline & Jumlah & $38.190,3$ & 100,0 & $38.190,3$ & 100,0 \\
\hline \multirow[t]{6}{*}{3.} & Total semua & JIII) & & & \\
\hline & $\mathrm{S}$ & $58.874,6$ & 32,0 & 123.821 & 67,3 \\
\hline & SB & $93.834,1$ & 51,0 & $30.398,6$ & 16,5 \\
\hline & TS & $28.261,9$ & 15,4 & $26.746,9$ & 14,5 \\
\hline & Tidak dinilai & $3.024,0$ & 1,6 & $3.024,0$ & 1,6 \\
\hline & Jumlah & $183.994,6$ & 100,0 & $183.994,6$ & 100,0 \\
\hline
\end{tabular}

Keterangan:

${ }^{1)}$ KKL : Kelas kemampuan lahan; S: Sesuai; SB: Sesuai bersyarat; TS: Tidak sesuai.

${ }^{2}$ KL-PL: Kesesuaian antara kemampuan lahan dengan penggunaan lahan aktual

${ }^{3)}$ KL-PR: Kesesuaian antara kemampuan lahan dengan alokasi lahan dalam pola ruang pada RTRWK

mampuan tinggi sampai sedang yang dapat digunakan untuk pertanian, yaitu lahan kelas I sampai kelas IV (dalam hal ini di Tuban hanya kelas II sampai kelas IV), sebagian besar penggunaannya masih sesuai dengan kemampuan lahannya. Total luas lahan kelas I sampai kelas IV adalah $142.780,3$ ha atau $77,6 \%$ dari luas wilayah. Pada kelompok ini, lahan yang penggunaannya sesuai dengan kemampuan lahannya adalah seluas 48.946,2 ha (atau 34,3\% dari luas lahan berkemampuan tinggi sampai sedang). Untuk lahan kelas II sampai kelas IV, penggunaannya untuk pertanian masih memungkinkan, namun tentunya dengan masukan untuk mengurangi pembatas, atau dengan kata lain, sesuai bersyarat. Lahan yang tergolong sesuai bersyarat adalah seluas $93.834,1$ ha, atau $65,7 \%$ dari luas lahan berkemampuan tinggi sampai sedang.

Pada lahan Kelas III yang tergolong sesuai bersyarat, terutama pada lahan yang berdrainase agak buruk dengan permeabilitas lambat, diperlukan perbaikan drainase. Pola tanam perlu dipilih pola yang dapat memperbaiki struktur tanah agar mudah diolah. Untuk mencegah pelumpuran dan meningkatkan permeabilitas tanah, perlu dilakukan penambahan bahan organik, disamping tidak mengolah tanah pada waktu basah. Lahan kelas IV yang tergolong sesuai bersyarat, karena faktor penghambatnya adalah lereng curam, bila digunakan untuk tanaman semusim diperlukan pembuatan teras bangku atau pergiliran dengan tanaman penutup tanah atau tanaman pakan ternak atau pupuk hijau selama 3 sampai 5 tahun.
Lahan-lahan yang harus dikelola dengan lebih hati-hati adalah lahan dengan kemampuan lahan agak rendah sampai rendah, yaitu lahan kelas $\mathrm{V}$ sampai kelas VIII, dalam hal ini di Tuban adalah lahan kelas VI dan VIII karena tidak ada lahan kelas V. Total luas lahan kelas V sampai VIII, atau lahan berkemampuan agak rendah sampai rendah di Tuban adalah 38.190,3 ha (atau 20,8\% dari luas wilayah). Dari total luas lahan yang berkemampuan agak rendah sampai rendah tersebut, sebagian diantaranya digunakan dengan melebihi kemampuannya, yaitu seluas $28.261,9$ ha (atau $74 \%$ dari luas lahan berkemampuan agak rendah sampai rendah).

Alokasi lahan dalam pola ruang pada RTRWK disajikan pada Gambar 5. Hasil analisis kesesuaian antara kemampuan lahan dengan alokasi lahan dalam pola ruang pada RTRWK disajikan pada Tabel 7, Tabel 8 dan Gambar 6. Hasil menunjukkan bahwa lahan dengan kemampuan tinggi sampai sedang (kelas kemampuan lahan I sampai kelas IV, atau dalam hal Kabupaten Tuban, lahan kelas II sampai kelas IV) sebagian lahan (seluas 112.381,7 ha atau $78,7 \%$ luas lahan berkemampuan tinggi sampai sedang) telah dialokasikan untuk penggunaan lahan yang sesuai dengan kemampuannya. Lahan seluas 30.398,6 ha (atau $21,3 \%$ dari luas lahan berkemampuan tinggi sampai sedang), alokasi pola ruangnya melebihi daya dukung kemampuan lahannya, namun masih memungkinkan digunakan secara bersyarat. Kualitas yang cukup baik dari RTRWK dapat dilihat dari tidak adanya alokasi lahan dalam pola ruang yang tidak sesuai dengan kemampuan 


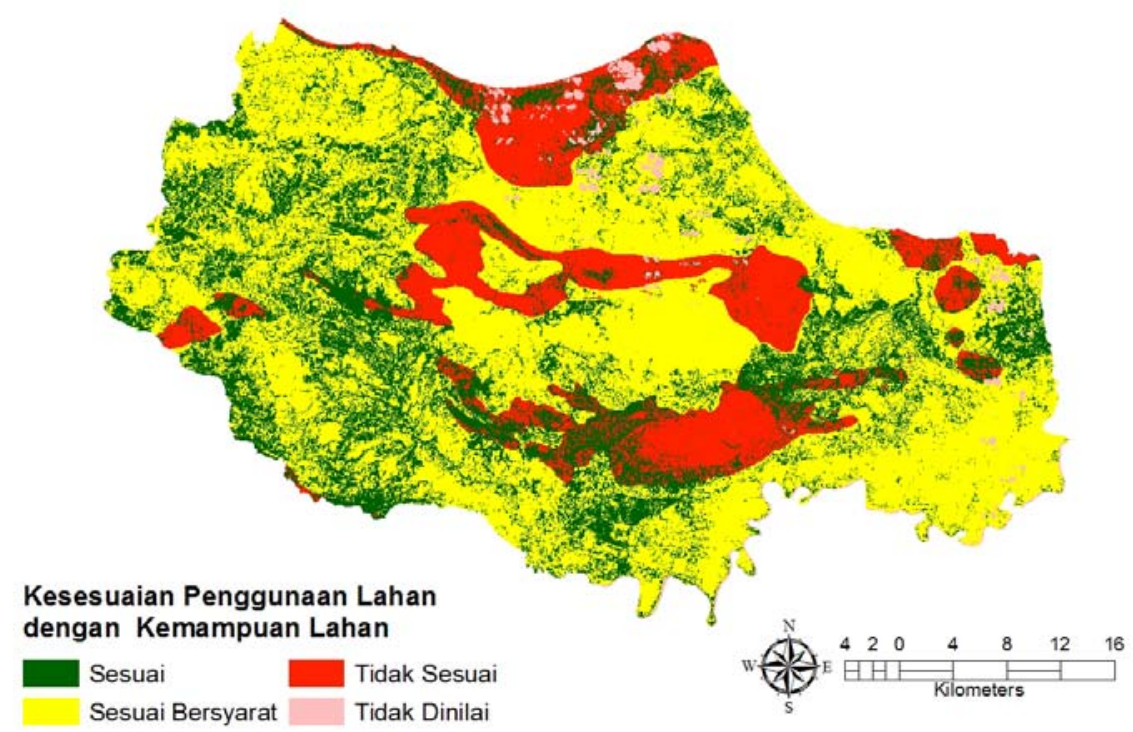

Gambar 4. Kesesuaian antara kemampuan lahan dengan penggunaan lahan aktual.

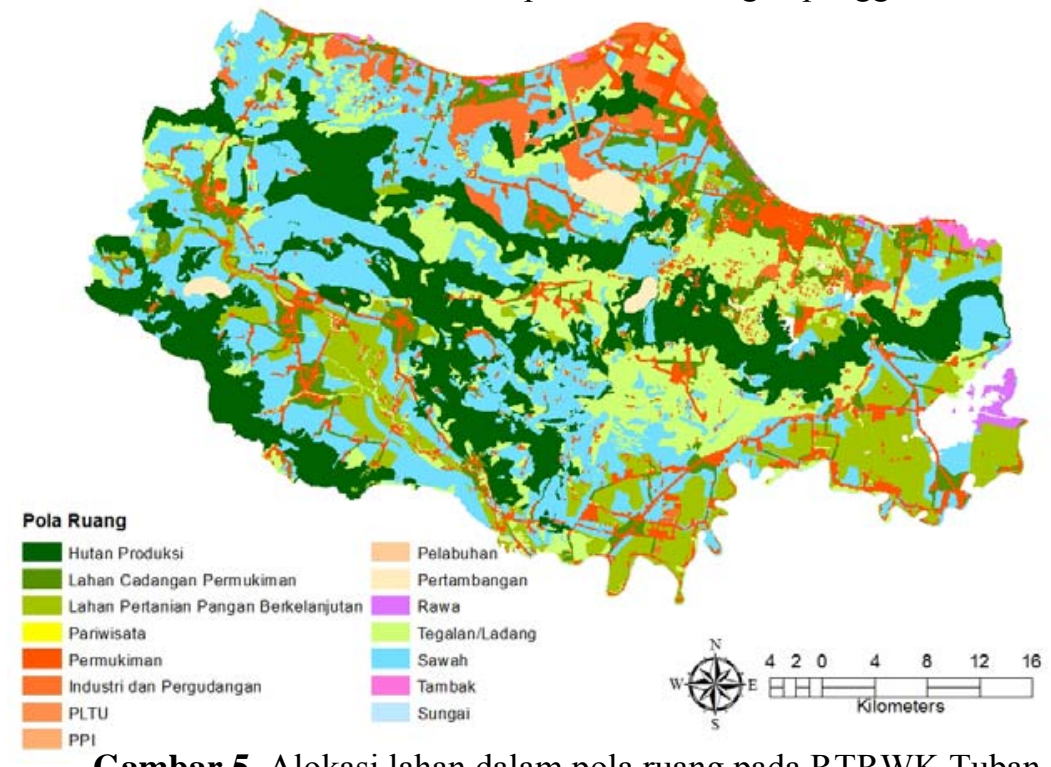

Gambar 5. Alokasi lahan dalam pola ruang pada RTRWK Tuban.

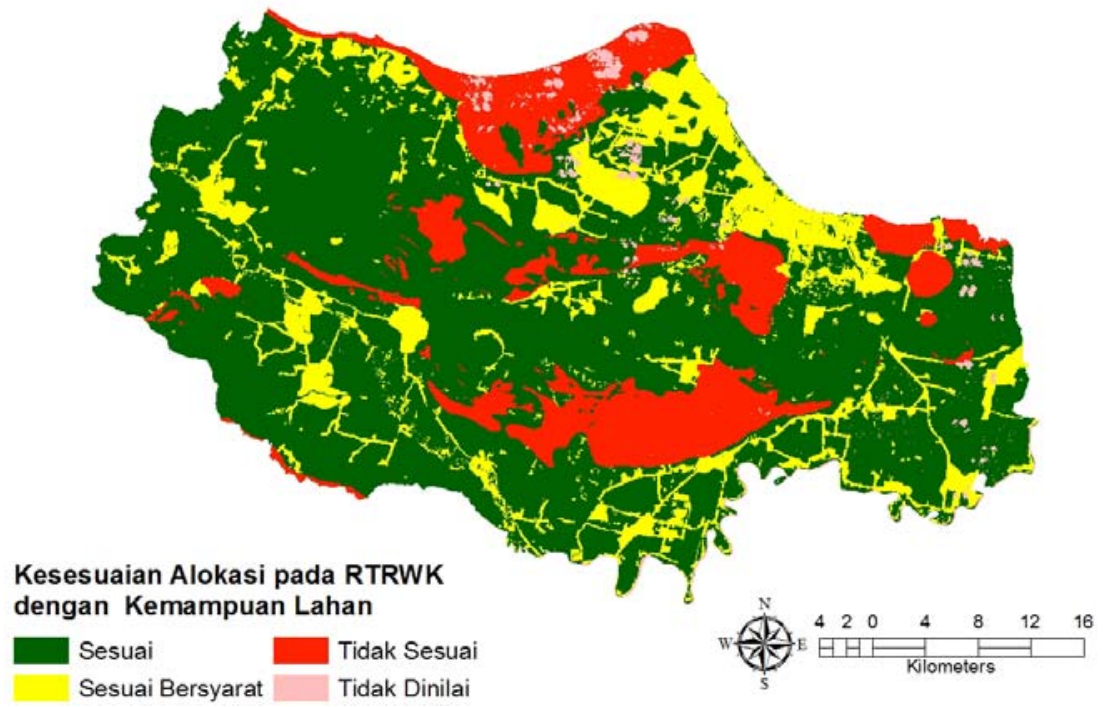

Gambar 6. Kesesuaian antara kemampuan lahan dengan alokasi lahan dalam pola ruang pada RTRWK. 
lahannya, khususnya pada lahan yang berkemampuan tinggi. Meskipun demikian, perlu diingatkan agar alokasi ini benar-benar diterapkan dalam bentuk pentaatan RTRWK agar penggunaan lahan pada masa mendatang tidak mengarah ke penggunaan lahan yang melebihi daya dukung lahannya.

Seperti halnya pada konfrontasi dengan penggunaan lahan aktual, ternyata alokasi pemanfaatan ruang berdasarkan RTRWK yang banyak melebihi daya dukung kemampuan lahannya terutama adalah pada lahan dengan kemampuan agak rendah sampai rendah, kelas $\mathrm{V}$ sampai kelas VIII. Pada lahan demikian, lahan seluas 26.746,9 ha (atau 70\% luas lahan berkemampuan agak rendah sampai rendah) dialokasikan tidak sesuai dengan kemampuan lahannya. Ini berarti, alokasi lahan dalam pola ruang pada RTRWK melebihi daya dukung kemampuan lahannnya. Contoh paling ekstrim adalah pada lahan-lahan kelas VIII, seluruhnya $(100 \%$ dari luas lahan kelas VIII) dialokasikan untuk penggunaan lahan yang melebihi kemampuannya (Tabel 8). Padahal, lahan demikian semestinya hanya dialokasikan untuk cagar alam atau hutan lindung.

Hasil analisis untuk seluruh Kabupaten Tuban ini secara umum menunjukkan penggunaan lahan aktual maupun alokasi lahan dalam pola ruang pada RTRWK telah cukup baik. Meskipun demikian, hasil menunjukkan pula perlunya penataan, baik dalam hal penggunaan lahan aktual maupun alokasi lahan dalam pola ruang resmi dalam RTRWK. Untuk bagian-bagian wilayah yang alokasinya dalam pola ruang pada RTRWK masih melebihi daya dukungnya, upaya pengaturan kembali melalui revisi RTRWK sangat disarankan dan bahkan mutlak diperlukan.

\section{KESIMPULAN}

Wilayah Kabupaten Tuban memiliki lahan dengan kelas kemampuan lahan berkisar dari kelas II sampai kelas VIII. Sebagian besar lahan memiliki kemampuan yang dapat mendukung usaha pertanian (kelas I sampai kelas IV), namun ada sebagian kecil lainnya yang seyogyanya tidak digunakan untuk budidaya (kelas V sampai kelas VIII). Faktor-faktor yang menjadi pembatas kemampuan lahan meliputi tekstur, kedalaman efektif, drainase, kemiringan lereng, dan bahaya banjir/genangan. Penggunaan lahan aktual di Kabupaten Tuban meliputi badan air, hutan, lahan kering, lahan pertanian, permukiman, sawah, semak belukar, tambak dan tanah terbuka. Hutan dan lahan pertanian merupakan penggunaan lahan paling dominan, diikuti tanah terbuka, semak belukar dan sawah. Secara keseluruhan, sebagian kecil lahan di Tuban telah digunakan sesuai dengan kemampuan lahannya, namun sebagian besar lahan digunakan melebihi kemampuan lahannya.

Pola ruang dalam RTRW Kabupaten Tuban telah mengalokasikan sebagian besar lahan secara sesuai dengan daya dukung berbasis kemampuan lahan. Meskipun demikian, masih ada sebagian kecil wilayah yang alokasi peruntukan lahannya melebihi daya dukung berbasis kemampuan lahannya.

Hasil penelitian ini menunjukkan bahwa diperlukan upaya-upaya konservasi lahan secukupnya bagi lahan-lahan yang secara aktual telah digunakan melebihi kemampuan lahannya. Penelitian ini juga dapat dijadikan masukan bagi revisi Rencana Tata Ruang Kabupaten pada siklus revisi 5 tahunan agar alokasi lahan dalam tata ruang lebih sesuai dengan daya dukung kemampuan lahannya.

\section{UCAPAN TERIMAKASIH}

Ucapan terimakasih disampaikan kepada Pemerintah Kabupaten Tuban untuk pembiayaan penelitian ini melalui DIPA Badan Perencanaan Pembangunan Daerah (Bappeda) Kabupaten Tuban Tahun Anggaran 2014, bekerjasama dengan Lembaga Penelitian dan Pemberdayaan Masyarakat (LPPM), Institut Pertanian Bogor berdasarkan Surat Perjanjian Kerjasama Nomor 329/IT3.11/DN/2014 (LPPM IPB) dan 188.45/04/414.102/2014 (Bappeda Kabupaten Tuban).

\section{DAFTAR PUSTAKA}

Adamu, G.K., Yusuf, M.A., dan Ahmed, M., 2014. Soil Degradation in Drylands. Academic Research International, 5(1):78-91.

Adnyana, I.W.S., dan Asy-syakur, A.R., 2012. Aplikasi Sistem Informasi Geografi (SIG) Berbasis Data Raster Untuk Pengkelasan Kemampuan Lahan di Provinsi Bali dengan Metode Nilai Piksel Pembeda. Manusia dan Lingkungan, 19(1):21-29.

Akinci, H., Ozalp, A.Y., dan Turgut, B., 2013. Agricultural Land Use Suitability Analysis Using GIS and AHP Technique. Computers and Electronics in Agriculture, 97:71-82.

Amiri, F., dan Shariff, A.R.B.M., 2012. Application of Geographic Information Systems in Landuse Suitability Evaluation for Beekeeping: A Case Study of Vahregan Watershed (Iran). African Journal of Agricultural Research, 7(1):89-97. 
Anonim, 1976. A Framework for Land Evaluation. Soils Bulletin, 32:72.

Anonim, 1987. Our Common Future. World Commission on Environment and Development. Oxford University Press. New York.

Anonim, 2010 . Klasifikasi Penutup Lahan. Standar Nasional Indonesia, No. 7645: 2010. Badan Standardisasi Nasional, Jakarta.

Anonim, 2010 b. Keys to Soil Taxonomy. 10th Edition. United State Department of Agriculture, Washington.

Anonim, 2011. Peta Sumberdaya Tanah Pulau Jawa dan Madura. Pusat Penelitian Tanah dan Agroklimat, Bogor.

Fenton, T.E., 2014. Land Capability Classification. In Encyclopedia of Natural Resources: Land. Taylor and Francis: New York. pp. 299-301.

Arsyad, S., 2010. Konservasi Tanah dan Air. IPB Press, Bogor

Badaruddin, Ruslan, M., Kusuma, Z., dan Rayes, M.L., 2013. An Analysis of Land Characteristics and Capabilities in Kusambi Sub-Watershed of Batulicin Watershed in Tanah Bumbu Regency, South Kalimantan. Journal Savap International, 4(5):222-233.

Bandyopadhyay, S., Jaiswal, R.K., Hegde, V.S., dan Jayaraman, V., 2009. Assessment of Land Suitability Potentials for Agriculture Using A Remote Sensing and GIS Based Approach. International Journal of Remote Sensing, 30(4):879-895.

Boix, L.R., dan Zinck, J.A., 2008. Land-Use Planning in The Chaco Plain (Burruyacu', Argentina), Part 2: Generating A Consensus Plan to Mitigate Land-Use Conflicts and Minimize Land Degradation. Environmental Management, 42:200-209.

Bulliqi, S., Isufi, F., Humolli, F., Stublla, A., dan Stublla, E., 2012. Land Resources in Lowland of Kosova and Their Utilization. Journal International of Environmental Application \& Science, 7(1):8-12.

Campos, S., Nardini, R.C., de Barros, Z.X., dan Cardoso, L.G., 2010. Geographic Information System Applied to Spatial Distribution of Land Use Capability. Pesq. Agropec. Trop., Goiânia, 40(2):174-179.

Chang, I-S., dan Wu, J., 2011. Review on Natural Resources Utilization in China. Management Science and Engineering, 5(2):16-21.

Costantini, E.A.C., 2009. Manual of Methods for Soil and Land Evaluation. Enfield, Science Publishers. pp. 549

Ditzler, C.A., dan Ahrens, R.J., 2006. Development of Soil Taxonomy in the United States of
America. Eurasian Soil Science, 39(2):141146.

Dougill, A.J., Twyman, C., Thomas, D.S.G., dan Sporton, D., 2002. Soil Degradation Assessment in Mixed Farming Systems of Southern Africa: Use of Nutrient Balance Studies for Participatory Degradation Monitoring. The Geographical Journal, 168(3):195-210.

Feizizadeh, B., dan Blaschke, T., 2012. Land Suitability Analysis for Tabriz County, Iran: A Multi-Criteria Evaluation Approach Using GIS. Journal of Environmental Planning and Management, 4:1-23.

Goldshleger, N., Ben-Dor, E., Lugassi, R., dan Eshel, G., 2010. Soil Degradation Monitoring by Remote Sensing: Examples with Three Degradation Processes". Soil Science Society of American Journal, 74:1433-1445.

Gupta, S., dan Sharma, R.K., 2010. Dynamic of Land Utilisation, Land Degradation and Factors Determining Land Degradation in Humachal Pradesh. Indian Journal of Agricultural Economics, 65(2):245-260.

Hardjowigeno, S., dan Widiatmaka. 2007.Evaluasi Lahan dan Perencanaan Tataguna Lahan. Gadjahmada University Press, Yogyakarta.

Helms, D., 1992. Readings in the History of the Soil Conservation Service. Soil Conservation Service, Washington, DC. pp. 60-73.

Klingebiel, A.A., dan Montgomery, P.H., 1961. Land capability classification. Agriculture Handbook, 210. Soil Conservation Service, U.S. Department of Agriculture. Washington, DC. pp. 1-3.

Maleknia, R., Mirarab, J., Moghaddam, M.N., dan Shahvali, A., 2013. An Ecological Capability Evaluation Model for Recreation, Conservation and Protection Functions of Iran's Zagro. International Journal of Agriculture: Research and Review, 3(2):458466, 2013.

Mokarram, M., dan Aminzadeh, F., 2010. GISBased Multicriteria Land Suitability Evaluation Using Ordered Weight Averaging with Fuzzy Quantifier: A Case Study in Shavur Plain, Iran. The International Archives of the Photogrammetry, Remote Sensing and Spatial Information Sciences, 38(2):508-512.

Munasinghe, M., 1993. Environmental Economics and Sustainable Development. World Bank Environment Paper No. 3, Washington DC.

Pilvere, I., Nipers, A., dan Upite, I., 2014. Agricultural Land Utilization Efficiency: The Case of Latvia. International Journal of Trade, Economics and Finance, 5(1):65-71. 
Sharififar, A., Ghorbani, H., dan Karimi, H., 2013. Integrated Land Evaluation for Sustainable Agricultural Production by Using Analytical Hierarchy Process. Agriculture (Polnohospodárstvo), 59(3):131-140

Singer, M.J., dan Munns, D.M., 2002. Soils: an Introduction. 5th ed. Prentice Hall, Englewood Cliffs, NJ.

Singer, M.J., 2014. Land Capability Analysis. In Encyclopedia of Natural Resources: Land. Taylor and Francis, New York, Published online: 21 Oct 2014, 295-298

Smardon, R., 2008. A comparison of Local Agenda 21 Implementation in North American, European and Indian Cities. Management of
Environmental Quality: An International Journal 19(1):118-137

Stocking, M.A., dan Murnaghan, N., 2002. Field Assesment of Land Degradation. Earthscan, London.

Sudershan, I., 2003. Environmental Damage to Land Resources - Need to Improve Land Use Data Base. Economic and Political Weekly, 38(34):3596 - 3604

Symeonakis, E., Calvo-Cases, A., dan ArnauRosalen, E., 2007. Land use change and land degradation in Southeastern Mediterranean, Spain. Environmental Management, 40:80-94.

Tan, K.H., 2009. Environmental Soil Science. 3rd edition. CRC Press, Boca Raton. pp. 557 